\title{
Inbound and Outbound Open Innovation: Organization and Performances
}

\author{
Francesca Michelino', Mauro Caputo², Antonello Cammarano ${ }^{3}$,Emilia Lamberti ${ }^{4}$
}

\begin{abstract}
The aim of the paper is to analyse the relationships between the openness degree of companies and their I) context features, 2) R\&D organization and 3) financial performances. The openness degree is defined after a pecuniary approach, involving all the transactions in the innovation market. Hypotheses are formulated and, then, tested on a sample of 126 world top R\&D spending bio-pharmaceutical companies for the period 2008-2012. Open innovation is more pervasive among small and young companies, for most of which it represents the very core business. Inbound and outbound practices have a similar diffusion in terms of number of companies adopting them, but the cumulative values of inbound flows are higher, whereas outbound flows are more relevant when compared to the total business of the firms. Inbound practices are substitutive to internal R\&D activities, while outbound ones are complementary to internal development. The performances of companies have an inverted-U shape trend versus inbound practices and a fundamentally decreasing trend versus outbound ones.
\end{abstract}

Keywords: open innovation; inbound open innovation; outbound open innovation; r\&d organization; financial performances; bio-pharmaceutical industry.

\footnotetext{
1,2,3 Department of Industrial Engineering, University of Salerno,Via Giovanni Paolo II, I32 - 84084 - Fisciano (SA), Italy. 'Phone: +39 089964068; e-mail: fmichelino@unisa.it 2Phone: +39 089964093; e-mail: mcaputo@unisa.it

3Phone: +39 089964023; e-mail: acammarano@unisa.it

${ }^{4}$ Department of Enterprise Engineering, University of Rome "Tor Vergata", Via del Politecnico, I - 00I33 - Roma (RM), Italy. Phone: +3908996206I; e-mail: emilia.lamberti@uniroma2.it
}

ISSN: 07 I8-2724. (http://www.jotmi.org)

Journal of Technology Management \& Innovation (c) Universidad Alberto Hurtado, Facultad de Economía y Negocios. 


\section{Introduction}

Since 2003, when Chesbrough introduced the open innovation $(\mathrm{Ol})$ paradigm, organizations are becoming more and more aware that they are unable to hold in-house all the competencies they require, thus forcing them to open up their research and development (R\&D) processes through pooling of collaborative activities and/or trading of intellectual property (IP) rights (Gassmann, 2006; West and Gallagher, 2006).

Open innovation has been one of the most discussed topics in innovation management literature in the last decade, with different approaches and different results.Academic research on open innovation is dominated by case studies or project experiences on how it is implemented and organized within firms (e.g., Dodgson et al., 2006), and survey studies on the adoption and performance implications of $\mathrm{Ol}$ strategies (e.g., Laursen and Salter, 2006). Although practice and theory seem to indicate that the open innovation approach is beneficial for companies, innovation measurement is still looking for an appropriate metrics system that monitors the investments and the effects of open versus closed innovation approaches, in order to help companies to find their right balance. The measurement of the value of open innovation activities is increasingly important and metrics systems are not yet adapted to monitor and measure the value of such activities. Only specific measurement systems allow for the successful implementation of open innovation and support the right capabilities (Enkel and Lenz, 2009).

In order to fill such a gap, we suggested a pecuniary definition of openness, based on the economic and financial flows that Ol transactions generate (Michelino et al., 20l4a). Starting from such definition, we investigate the relations between the adoption of open innovation modalities, the structural configurations of companies and their performances.

In particular, the aim of the paper is to analyse the relationship between the openness degree of companies and a set of variables linked to context features, R\&D organization and financial performances. Our research questions are: I) how the adoption of $\mathrm{Ol}$ practices can be linked to the size and the age of companies; 2) how inbound and outbound practices are related to each other and to internal R\&D activities; 3 ) how the adoption of OI practices is linked to financial performances of companies.

We tested our hypotheses on a sample of 126 world top R\&D spending bio-pharmaceutical companies selected from The 20II EU Industrial R\&D Investment Scoreboard, for which we collected annual report data for the five-years period 2008-2012, for a total of 630 statistical units.
In section 2, literature review is reported, with the main contributions on the relationships between open innovation and the other phenomena under study, and hypotheses are formulated. The description of the sample and the operationalization of the constructs are provided in section 3. Section 4 shows the results and conclusions are drawn in section 5 .

\section{Literature review and development of the hypotheses Context features}

The size of the firm is used by various studies as a variable potentially influencing open innovation adoption. In particular, many literature contributions (Chesbrough, 2003; Chesbrough and Crowther, 2006) indicate that the new innovation management paradigm is more intensively adopted by large firms.

Different studies (Laursen and Salter, 2006; Keupp and Gassmann, 2009) found a positive relationship between the firm size and Ol breadth and depth; Faems et al. (2010) detected a significant positive relationship between company size and alliance portfolio diversity. Schroll and Mild (20II) found that firm size has a strong correlation with the adoption of $\mathrm{Ol}$ practices and also Bianchi et al. (20II) found that the largest firms implement organizational modes of open innovation on average I,5 times more than the medium-sized and the smallest ones. Further, the study conducted by Inauen and Schenker-Wicki (20II) reveals statistically significant correlations between company size and cooperation intensity with regard to competitors, cross-industry firms, consulting firms and universities and Sandulli et al. (2012) found that large corporations are more likely to collaborate in the innovation process.

Different results are provided by Barge-Gil (2010) who found that open innovators are smaller than semiopen ones and larger than closed innovators, precluding a general conclusion on the relationship between openness and firm size.

No support for a linear relation between size and openness is provided by Podmetina et al. (201 I), who found that companies of different size, rather than having different degrees of openness, adopt different open business models, the smallest firms being more active in technology acquisition, the largest ones in technology commercialization. 
Other researchers have focused on the question of whether and how much SMEs are using OI. In their study on Dutch SMEs, van de Vrande et al. (2009) found that larger SMEs have higher levels of adoption than smaller ones. Lee et al. (2010) explain the reduced openness of SMEs through lack of infrastructure and financial resources. Furthermore, Idrissia et al. (2012) found that the increase in size helps SMEs to move from a closed cluster to interactive, user, and open clusters.

From all the previous considerations, we would expect that size has a positive impact on the likelihood of adopting open innovation strategies, since larger firms have a stronger technological position and greater resources if compared to smaller ones.

Hp. I: Firm size positively influences the adoption of open innovation.

The second context feature we analysed is firm age. Such a variable can be related to firm experience and learning, and is commonly used in empirical studies of innovation (Kumar and Saqib, 1996).

Different scholars found that age does not seem to be a predictor of openness degree (Keupp and Gassmann, 2009; Schroll and Mild, 20II). On the contrary, Teirlinck and Poelmans (2012) found that different relationships between age and openness degree can be found in different industries: cooperating firms in pharmaceuticals tend to be relatively young, whereas cooperation in basic chemicals takes place in longer established companies. Moreover, Idrissia et al. (20I2) suggest that age is a significant variable to explain the likelihood that SMEs move from closed to open clusters: the younger the company, the lower the likelihood for SMEs to be in an open cluster.

Thus, we expect that age has a positive impact on the likelihood of adopting open innovation strategies, since aging provides companies with experience needed to forge more relations and trust with external partners.

Hp. 2: Firm age positively influences the adoption of open innovation.

\section{R\&D organization}

Empirical studies examining Ol adoption modalities have constantly found that companies perform more inbound than outbound activities even if, by definition, every inbound effort from one organization should generate a reciprocal outbound effort from another one (Chesbrough and Crowther, 2006).

Van der Meer (2007) describes Dutch firms as reluctant to take part in the use of exporting mechanisms (i.e. outbound practices), with only $54 \%$ highly innovative companies using them vs. $74 \%$ adopting importing mechanisms (i.e. inbound practices). Similarly, van de Vrande et al. (2009), using the concept of technology exploration and exploitation respectively linked to inbound and outbound - found that exploitation activities are pursued by less than $30 \%$ of their sample, whereas exploration ones were adopted by more than $90 \%$. Further, Schroll and Mild (20I I) found that companies adopt more inbound cooperation (4,03 on a seven-point Likert scale) than outbound activities $(2,92)$.

Similar results are provided in contributions focused on specific industries: the studies of Chiaroni et al. (2009) and Bianchi et al. (20II) in the bio-pharmaceutical industry highlight that more than $60 \%$ of the Ol activities pursued by companies are linked to inbound practices. The same findings are also obtained in the German automotive industry, where Ili et al. (2010) found that only one supplier in the sample of 42 companies was actively exploiting unused patents, which were not suitable to its portfolio.

In his special issue on open innovation, Huizingh (20II) gives different explanations to the fact that empirical studies find so much more use of inbound Ol. One possibility is that while many organizations use external knowledge, only a few provide it; other potential explanations are that either the measurement scales, the respondents, or the samples in these studies are biased. $\mathrm{He}$ also argues that further research could clarify this issue.

From all the previous observations, it follows that inbound activities are generally more frequent than outbound ones.

Hp. 3: The adoption of inbound activities is higher than the adoption of outbound activities. 
However, it is possible to hypothesize that the adoption level of outbound activities can be influenced by that of inbound ones. In this line, Schroll and Mild (20II) found that the more a company adopts inbound Ol methods, the more it will also adopt outbound ones. As a matter of fact, if a firm is using inbound activities for additional creation of innovations, it is probable that it will leverage unused parts of its increased pool of innovations and IP by the means of outbound innovation.

Hence, we expect a higher likelihood of pursuing outbound practices when inbound open innovation is adopted.

Hp. 4: The adoption of inbound open innovation positively influences the adoption of outbound open innovation.

One of the issues that is most often discussed in empirical Ol literature is the relationship between the internal R\&D activities of a firm and the level of open innovation adoption.

From one hand, internal R\&D is usually employed as a proxy for absorptive capacity (Cohen and Levinthal, 1990) that can be related to higher ability of the firm to integrate external knowledge into the product development process and, consequently, to a smoother adoption of the open innovation paradigm. On the other hand, firms with lower internal R\&D might need more external knowledge. Hence, this variable may have contradictory effects on the adoption of Ol: in literature different studies suggest open innovation as either substitute or complementary to internal R\&D.

Laursen and Salter (2006) uncovered a negative interaction effect between internal R\&D and open innovation, which might be explained by a greater propensity of research intensive firms to exhibit the so-called not-invented-here syndrome (Katz and Allen, 1982). In addition, Faems et al. (2010) found an indirect relationship between the diversity of the technology alliance portfolio and product innovation performance via internal R\&D intensity.

Conversely, van de Vrande et al. (2009) stated that the range of possibilities that open innovation practices offer is wider for large SMEs than for small ones since the former have more formalized internal R\&D and innovation practices. In addition, by evaluating the motivations of specific types of open innovation, the authors found that a vital reason for the outsourcing of R\&D is to gain from complementary resources in order to spread the risks and to compensate for a lack of current R\&D capacity. Further, Chesbrough and Crowther (2006) also found a stable or increased R\&D spending in organizations where open innovation was adopted, suggesting the role of open innovation as a complement for internal R\&D. According to Lazzarotti et al. (2010), open innovators spend significantly more on R\&D and also Podmetina et al. (20II) found a significantly higher value of R\&D intensity for the companies developing open innovations.

However, none of the above scholars distinguished between the inbound and outbound modes of Ol.An exception is the study by Schroll and Mild (20II). The authors found that, generally, open innovation seems to be a complement to internal R\&D but that an increased use of inbound activities is employed as a substitute for internal R\&D. Hence, inbound open innovation activities can reduce the R\&D intensity of a company.

From all the previous considerations, it is possible to hypothesize a complementarity between the investment in internal R\&D activities and open innovation adoption, both because higher levels of internal R\&D imply higher level of absorptive capacity and thus favour inbound practices and because higher levels of internal R\&D generate more innovations that can be leveraged by the means of outbound open innovation.

Hp. 5a: Inbound open innovation is complementary to internal $R \& D$ activities.

Hp. 5b: Outbound open innovation is complementary to internal R\&D activities.

\section{Financial performances}

The impact of open innovation on firms' financial performances has been explored by different studies.

Dahlander and Gann (2007) argue that it is not true that "the more openness, the better" since it can be costly and it is not always easy to have a high degree of openness. Indeed, the approach chosen by companies should depend on its coherence with the strategic, organizational and managerial contexts and on an acceptable balance between the benefits and costs.

Some contributions support the existence of a positive relationship between $\mathrm{OI}$ and firm performances. Collecting survey data from Taiwanese electronic-product manufacturers, Hung and Chiang (2010) found a positive relationship between open innovation proclivity and firm performances measured through theWiklund and Shepherd's (2003) scale.Ju et al.(2013) explored the relationships among open innovation processes, entrepreneurial orientation, and organizational performances (innovation and financial) of SMEs. Their empirical results reveal that the inbound process is positively related to both performance outcomes, the outbound process to financial performance, and the coupled process to innovation performance. 
Ahn et al. (2013) analysed the relationships between open innovation capacities and financial performance assessed in terms of sales and operating profit, using the Korean Innovation Survey 2008 data. The analysis suggests that all Ol capacities are significantly associated with firms' financial performance but some are negatively associated, implying the possibility of delayed effects.

According to Faems et al. (2010), the research has usually focused on the value-enhancing effects of Ol, but not on the increased costs of a more diverse technology alliance portfolio. As a matter of fact, when a firm comes to rely more on external inputs, its search and partnering costs may increase. In particular, in the short-term, the direct costincreasing effect of technology alliance portfolio diversity is larger than the indirect value-generating effect of technology alliances, resulting in an aggregated negative effect of diversity of technology alliance portfolios on financial performance. Furthermore, Hwang and Lee (2010) examined the role of external knowledge search breadth and depth on productivity, calculated as firm total sales divided by the number of employees, finding that they both have a significant influence on labour productivity. In particular, breadth has a $U$ relationship with labour productivity while depth an inverse- $U$ relationship.This implies that the moderate use of external knowledge sources increases labour productivity, but only the limited number of external sources with innovative importance are effective in improving it.

By taking into account not only the benefits of open innovation, but also the costs associated with its adoption, we posit the following hypothesis.

Hp. 6: Financial performances of companies have an inverted-U relationship with open innovation adoption.

All the hypotheses can be summarized in Figure I.

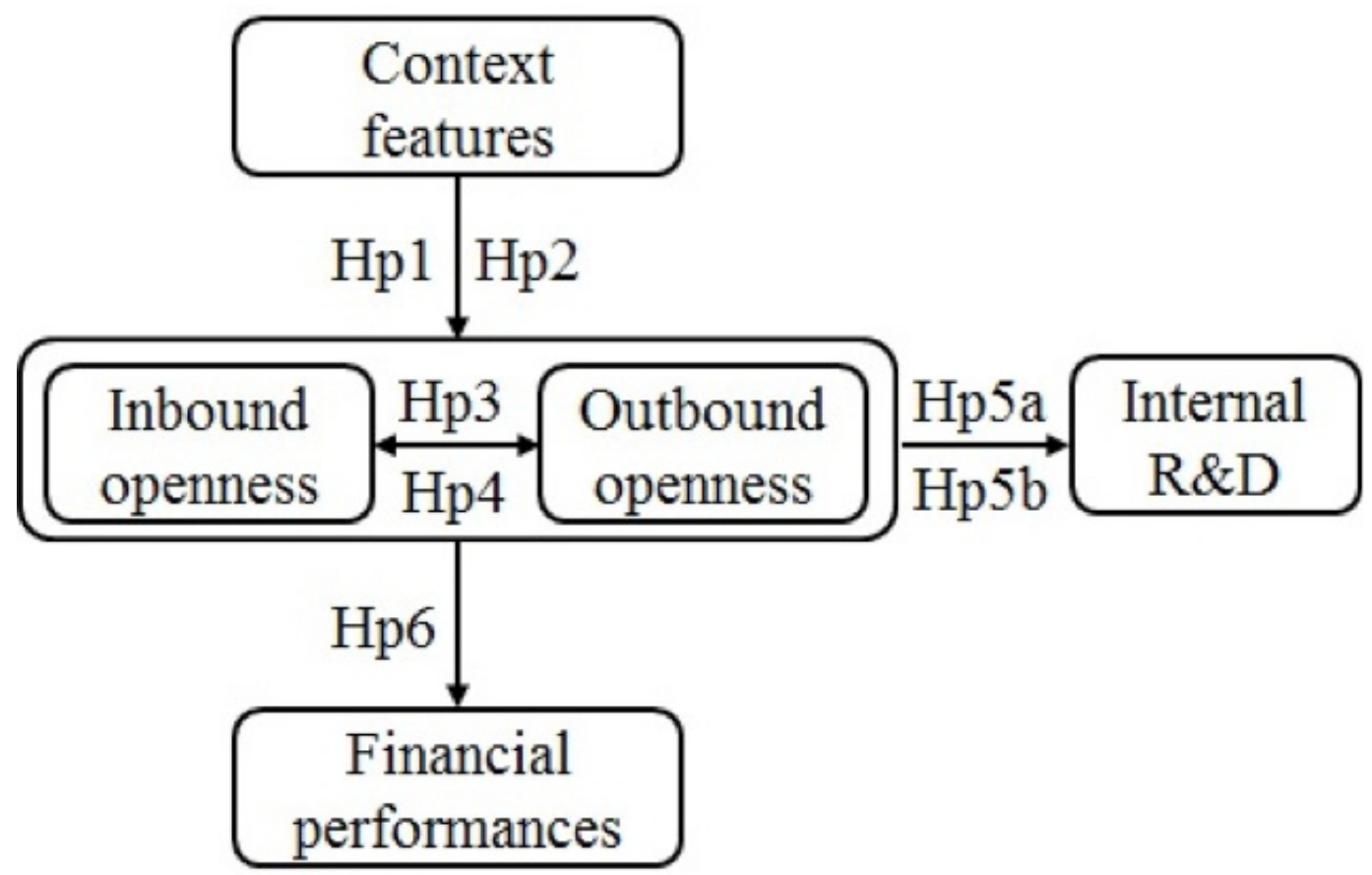

Figure I.The research hypotheses. 
Research methodology Sample and data collection

The hypotheses were tested by analysing a sample of biopharmaceutical companies, given the high relevance open innovation has in such industry. The industry is, in fact, an early pioneer of OI (Cooke, 2005; Chesbrough and Crowther, 2006; Fetterhoff and Voelkel, 2006; Kleyn et al., 2007; Chiaroni et al., 2008) because of the high relevance of R\&D and the distributed nature of knowledge (Powell et al., 2005), and has a broad spectrum of Ol models which have already become a standard in it (Gassmann et al., 2008).

We considered a sample of 126 world top R\&D spending companies, ranked by The 20I I EU Industrial R\&D Investment Scoreboard, for which we analysed the consolidated annual reports from 2008 to 2012 , for a total of 630 statistical units.

The Scoreboard reports 229 bio-pharmaceutical companies, but 85 companies were excluded because their annual reports, available on the internet, were either incomplete, with no notes to the consolidated balance sheet and income statement, or not filling IFRS or US GAAP standards. Further, 18 companies were excluded since some of their annual reports were not available on the internet, because they were acquired during the five-years period. The final sample consists of 77 European companies and 49 nonEuropean ones: the most represented country is USA with 42 companies, followed by UK (I4) and Germany (13).

\section{Measures}

We adopted a pecuniary approach to the measurement of the openness degree of companies, by analysing their OI transactions. According to literature (Gassmann and Enkel, 2004), open innovation is characterized by two different dimensions: inbound and outbound.

On the economic side, inbound transactions include the costs deriving from I) collaborative R\&D projects, 2) outsourcing of R\&D services and 3) in-licensing, and, on the financial one, the acquisition of innovation-related intangibles (i.e.additions), such as development costs, patents, product rights or technology. In the same way, outbound transactions include revenues from I) R\&D collaboration, 2) R\&D services performed on behalf of third parties and 3) out-licensing, as well as the selling of innovation-related intangibles (i.e. disposals).

In order to understand how pervasive open innovation is within the business of a company, open costs and revenues, additions and disposals of intangibles have to be compared respectively to total R\&D and IP costs, total revenues and total intangibles, so that two measures of openness can be defined:

$$
\begin{aligned}
& \text { Inbound }=\sqrt{\frac{1}{2}\left[\left(\frac{\text { open costs }}{R \& D+I P \text { costs }}\right)^{2}+\left(\frac{\text { additions }}{\text { intangibles }}\right)^{2}\right]} \\
& \text { Outbound }=\sqrt{\frac{1}{2}\left[\left(\frac{\text { open revenues }}{\text { revenues }}\right)^{2}+\left(\frac{\text { disposals }}{\text { intangibles }}\right)^{2}\right]}
\end{aligned}
$$

In addition to openness metrics, the following context variables and financial performances were considered:

- firm size, defined as the number of employees;

- firm age, measured in number of years from the date of establishment;

- closed R\&D per employee, where closed R\&D is measured as total R\&D and IP costs net of open costs;

- closed EBIT per employee, where closed EBIT is measured as EBIT net of open revenues less open costs;

- closed ROA, measured as closed EBIT divided by total assets;

- market capitalization on total assets.

The data were used after a cross-section perspective, since five years are not enough for a longitudinal study, especially in an industry where the development time horizon can be longer than ten years.

ISSN: 07 I8-2724. (http://www.jotmi.org) 


\section{Empirical results}

Table I shows descriptive statistics and correlations between all the variables under study.

\section{Context features}

Table 2 shows the results of regression analyses performed using firm size and age as predictors and inbound and outbound as dependent variables.

\begin{tabular}{|c|c|c|c|c|c|c|c|c|c|c|}
\hline & Mean & SD & 1. & 2. & 3. & 4. & 5. & 6. & 7. & 8. \\
\hline I. inbound & $18,5 \%$ & $20,8 \%$ & 1 & & & & & & & \\
\hline 2. outbound & $25,6 \%$ & $29,2 \%$ &, $106 * *$ & 1 & & & & & & \\
\hline 3. firm size & 10.340 & 25.146 &,$- 107^{* *}$ &,$- 330 * *$ & 1 & & & & & \\
\hline 4. firm age & 42 & 47 &,$- 157 * *$ &,$- 446 * *$ &, $484 * *$ & 1 & & & & \\
\hline 5. closed R\&D per employee & $116 k €$ & $\begin{array}{l}117 \\
k €\end{array}$ &,$- 165 * *$ &, $531 * *$ &,$- 215 * *$ &,$- 359 * *$ & 1 & & & \\
\hline 6. closed EBIT per employee & $-8 \mid k €$ & $\begin{array}{l}233 \\
k €\end{array}$ & ,090* &,$- 689 * *$ &, $280 * *$ &, $333 * *$ &,$- 67 \mid * *$ & I & & \\
\hline 7. closed ROA & $-13,5 \%$ & $39,9 \%$ & , 070 &,$- 613 * *$ &, $264 * *$ &, $346 * *$ &,$- 463^{* *}$ & ,689** & 1 & \\
\hline $\begin{array}{l}\text { 8. market capitalization on } \\
\text { assets }\end{array}$ & 2,76 & 17,01 &,- 031 & 022 &,- 036 &,- 043 & 050 &,$- 166 * *$ &,$- 212 * *$ & I \\
\hline
\end{tabular}

Table I. Mean, standard deviation and correlations

(** the correlation is significant at $0,0 \mathrm{I}$ level, ${ }^{*}$ the correlation is significant at 0,05 level).

\begin{tabular}{|c|c|c|c|c|c|c|c|c|}
\hline & \multicolumn{4}{|c|}{ Dependent variable: inbound } & \multicolumn{4}{|c|}{ Dependent variable: outbound } \\
\hline Adjusted $\mathrm{R}^{2}$ & \multicolumn{4}{|c|}{,023 } & \multicolumn{4}{|c|}{,214 } \\
\hline $\begin{array}{l}\text { Std. error of the } \\
\text { estimate }\end{array}$ & \multicolumn{4}{|c|}{,205 } & \multicolumn{4}{|c|}{,259 } \\
\hline ANOVA: & \multirow{2}{*}{\multicolumn{2}{|c|}{$\begin{array}{c}\text { Regression } \\
, 702\end{array}$}} & \multicolumn{2}{|c|}{ Residual } & \multicolumn{2}{|c|}{ Regression } & \multicolumn{2}{|c|}{ Residual } \\
\hline Sum of squares & & & 26 & & & 597 & 42 , & \\
\hline df & \multirow{2}{*}{\multicolumn{2}{|c|}{$\begin{array}{c}2 \\
, 351\end{array}$}} & \multicolumn{2}{|c|}{627} & \multicolumn{2}{|c|}{2} & \multicolumn{2}{|c|}{627} \\
\hline Mean square & & & 0 & & & 99 & 0 & \\
\hline $\mathrm{F}$ & \multicolumn{4}{|c|}{8,327} & \multicolumn{4}{|c|}{86,374} \\
\hline Sig. & \multicolumn{4}{|c|}{,000 } & \multicolumn{4}{|c|}{,000 } \\
\hline Predictors: & \multirow{4}{*}{$\begin{array}{c}\text { B } \\
, 214 \\
-3 \mathrm{E}-07 \\
-, 001\end{array}$} & $\begin{array}{r}\text { Std. } \\
\text { erro }\end{array}$ & $\mathrm{t}$ & Sig. & \multirow{4}{*}{$\begin{array}{c}B \\
, 371 \\
-2 E-06 \\
-, 002\end{array}$} & $\begin{array}{l}\text { Std } \\
\text { erro }\end{array}$ & $\mathrm{t}$ & Sig. \\
\hline constant & & ,011 & 19,506 & ,000 & & , 01 & 26,837 & ,000 \\
\hline firm size & & ,000 & $-0,906$ & ,365 & & , 00 & $-3,685$ & ,000 \\
\hline firm age & & ,000 & $-3,044$ & ,002 & & ,00 & $-9,259$ & ,000 \\
\hline
\end{tabular}

Table 2. Linear regressions of inbound and outbound using context features as predictors

ISSN: 07 I8-2724. (http://www.jotmi.org) 
Size has no significant effect on inbound and a negative effect on outbound, thus Hp. I is only partially significant, but with the opposite sign. Firm age negatively affects both inbound and outbound, so that Hp. 2 is significant with the opposite sign.

The difference in the results can be primarily explained with the different approach used to define the openness of companies. The most widespread measures of openness include the number of external sources of knowledge, the alliance portfolio diversity and the number of different open activities in which a company is involved. All such measures increase with the company size, because of the resources that can be devoted to the management of different relationships, as well as with its age, because of the larger number of collaboration opportunities along its life.

Our approach to the measurement of openness, rather than evaluating the wideness of linkages with third parties or the number of different open activities, focuses on how much Ol is pervasive in the company in terms of importance for its business, e.g. how much open costs count over total R\&D and IP costs. Thus, even if a small, young company has a limited number of external linkages or performs a limited number of open activities, the pecuniary flows deriving from such linkages/activities can be very high, especially if compared to its total volume of business.

A result consistent with literature would be achieved if, instead of measuring openness through ratios, the total values of open costs, revenues, additions and disposals were used. Actually, the total open flows are typically higher for larger companies even if their importance for the total business of the company is marginal. For example, in 2012 Roche achieved about I,4 billion euro from its open activities which, compared to the 39 billion of total revenues, equals to $3,6 \%$; on the other side, Sygnis Pharma achieved $100 \%$ of its 0,4 million euro revenues through open innovation. After our approach Sygnis is more open than Roche, since $\mathrm{Ol}$ is a more pervasive behaviour and has a more important effect on the business of the former. If total values would be used, Roche would be more open than Sygnis and a positive relation would be found between openness and firm size.

\section{R\&D organization}

Hp. 3 is rejected by the use of both frequency and intensity (Table 3).

Frequency is the number of companies which adopted open practices in the five-years period analysed - i.e. the number of non-zero values for inbound and outbound metrics while intensity is the value of the metrics themselves.

In our sample outbound practices are slightly more frequent than inbound ones and the mean value of outbound transactions - when compared to the total business of companies - is slightly higher than the mean value of inbound ones.

Once again, if total values of open flows were considered instead of ratios, the opposite result would be achieved, with inbound transactions totalling 43,7 billion euro costs and 286,8 billion additions and outbound transactions totalling 58 , I billion revenues and I3,5 billion disposals.

Ideally, any inbound flow for a company should generate an outbound flow for another one, so that the two values should be the same.Yet, being our sample limited to only 126 companies in the bio-pharmaceutical industry we do not expect a perfect equality of inbound and outbound flows, which is expected only when the total industry is analysed. Further, some more explanations can be given to such dissymmetry. Comparing revenues and costs points out that the former are slightly higher than the latter: this may be due to the fact that not all the expenses in R\&D are registered as costs, since, when accounting criteria are satisfied, they can be reported in the balance sheet as capitalization. This remark is also consistent with the higher value of additions if compared to disposals, even if it is not the unique motivation for the disparity. A second reason is, in fact, the presence of goodwill ( 89,0 billion euro) which can be viewed as the difference between how much the buyer pays (addition) and how much was registered in the balance sheet of the seller (disposal). The third motivation is linked to the fact that when a whole company is acquired, an addition is registered for the acquiring firm, but no disposal can be found, since the

\begin{tabular}{|l|c|c|}
\hline & inbound & outbound \\
\hline number of companies & 537 & 584 \\
\hline percentage of companies & $85,24 \%$ & $92,70 \%$ \\
\hline mean value & $18,51 \%$ & $25,61 \%$ \\
\hline
\end{tabular}

Table 3. Descriptive statistics for inbound and outbound.

ISSN: 07 I8-2724. (http://www.jotmi.org)

Journal of Technology Management \& Innovation (c) Universidad Alberto Hurtado, Facultad de Economía y Negocios. 
acquired company disappears and no annual report is drawn. Also Hp. 4 is tested as to both frequency and intensity and it resulted significant with the opposite sign, i.e. in the selected sample companies adopting inbound practices are less inclined to adopt outbound ones. Even if correlation between inbound and outbound is weakly positive (Table I), the regression analysis does not support the causative relationship being R2 too low (data not shown). Further, the percentage of companies adopting outbound practices in the whole sample is slightly lower than the percentage among those not adopting inbound practices (Table 4) and the mean intensity of outbound in the sub-sample of companies not performing inbound is almost two times higher than the intensity for companies performing inbound (Table 5). Such difference in the mean values is statistically significant, as confirmed through the one-way ANOVA (Table 6).

\begin{tabular}{|l|c|c|c|}
\hline & not performing outbound & performing outbound & total \\
\hline not performing inbound & $3(3,2 \%)$ & $90(96,8 \%)$ & $93(100 \%)$ \\
performing inbound & $43(8,0 \%)$ & $494(92,0 \%)$ & $\begin{array}{c}537 \\
(100 \%)\end{array}$ \\
\hline total & $46(7,3 \%)$ & $584(92,7 \%)$ & $\begin{array}{c}630 \\
(100 \%)\end{array}$ \\
\hline
\end{tabular}

Table 4. Number (percentage) of companies performing and not performing inbound and outbound activities: crosstab

\begin{tabular}{|l|c|c|}
\hline & outbound mean & outbound SD \\
\hline not performing inbound & $43,8 \%$ & $29,4 \%$ \\
\hline performing inbound & $22,5 \%$ & $28,0 \%$ \\
\hline total & $25,6 \%$ & $29,2 \%$ \\
\hline
\end{tabular}

Table 5. Outbound mean and standard deviation for companies performing and not performing inbound activities.

\begin{tabular}{|l|c|c|c|c|c|}
\hline & Sum of squares & df & Mean square & F & Sig. \\
\hline $\begin{array}{l}\text { Between } \\
\text { groups }\end{array}$ & 3,627 & $\mathrm{I}$ & 3,627 & \multirow{2}{*}{45,492} & \multirow{2}{*}{, 000} \\
\hline Within groups & 50,064 & 628 &, 080 & & \\
\hline
\end{tabular}

Table 6. One-way ANOVA for outbound using inbound as a predictor.

ISSN: 07 I8-2724. (http://www.jotmi.org)

Journal of Technology Management \& Innovation (c) Universidad Alberto Hurtado, Facultad de Economía y Negocios. 
Once again, the results would be different if we considered the total values of Ol flows instead of ratios: the total value of open revenues for the companies adopting inbound practices is 55,5 billion euro versus 2,6 billion euro for those non performing inbound; an even more significant difference is registered as to disposals ( 13,2 vs. 0,2 billion).

Hp. $5 a$ is significant with the opposite sign while $\mathrm{Hp.} 5 \mathrm{~b}$ is confirmed (Table 7).

Inbound practices were found to be substitutive to internal R\&D, while outbound ones can be considered complementary.Actually, inbound activities and internal R\&D both represent efforts that a company puts in its innovation process, while outbound practices can be considered as a result of such process. Thus, if the two typologies of input - internal resources vs. external ones - can be considered as substitutive, it is not surprising that a higher level of internal R\&D generates more innovation outputs that can be exploited through outbound practices.

\section{Financial performances}

In order to test the inverted-U shape of performances, quadratic regressions were performed with closed EBIT per employee, closed ROA and market capitalization on assets as dependent variables and inbound, outbound, their squares and their product as predictors.

Both closed EBIT per employee and closed ROA provide a partial confirmation to Hp. 6 (Table 8), while market capitalization on assets regression is not significant (data not shown).

In particular, the hypothesis is confirmed as to inbound, since the first-power term has a positive coefficient, the secondpower one a negative coefficient. On the contrary, the coefficients of outbound suggest an opposite trend, i.e. an $U$ shape. The trends of closed EBIT per employee vs. inbound (outbound) for different values of outbound (inbound) are reported in Figure 2a (b). Similar trends are obtained for closed ROA (figures not shown).

\begin{tabular}{|c|c|c|c|c|}
\hline & \multicolumn{4}{|c|}{ Dependent variable: closed R\&D per employee } \\
\hline Adjusted $R^{2}$ & \multicolumn{4}{|c|}{329} \\
\hline $\begin{array}{l}\text { Std. error of the } \\
\text { estimate }\end{array}$ & \multicolumn{4}{|c|}{95,607} \\
\hline ANOVA: & \multicolumn{2}{|c|}{ Regression } & \multicolumn{2}{|c|}{ Residual } \\
\hline Sum of squares & \multicolumn{2}{|c|}{2.836 .868} & \multicolumn{2}{|c|}{5.731 .248} \\
\hline df & \multicolumn{2}{|c|}{2} & \multicolumn{2}{|c|}{627} \\
\hline Mean square & \multicolumn{2}{|c|}{1.418 .434} & \multicolumn{2}{|c|}{9.141} \\
\hline $\mathrm{F}$ & \multirow{2}{*}{\multicolumn{4}{|c|}{$\begin{array}{c}155,177 \\
, 000\end{array}$}} \\
\hline Sig. & & & & \\
\hline Predictors: & B & Std. error & $\mathrm{t}$ & Sig. \\
\hline constant & 82,516 & 5,918 & 13,943 & 000 \\
\hline inbound & $-125,920$ & 18,458 & $-6,822$ & 000 \\
\hline outbound & 221,445 & 13,122 & 16,875 & ,000 \\
\hline
\end{tabular}

Table 7. Linear regression of closed R\&D per employee using inbound and outbound as predictors.

ISSN: 07 I 8-2724. (http://www.jotmi.org) 
It is possible to observe that, for any fixed value of outbound, both performance indicators increase with the value of inbound until a maximum is reached and then begin to decrease. Closed EBIT per employee reaches its maximum for values of inbound ranging from $43 \%$, when outbound is equal to zero, to $58 \%$, when outbound is equal to $100 \%$. It is noteworthy that only the curve corresponding to no outbound shows positive values of the ratio, so that for any value of outbound greater than or equal to $20 \%$ a negative EBIT should be expected. This is confirmed by the trends in Figure $2 b$, where closed EBIT per employee is positive only for outbound less than or equal to $18 \%$. The curves with inbound less than $60 \%$ show a decreasing trend vs. outbound, while when inbound is greater than or equal to $60 \%$ the performances have an $U$ shape, reaching a minimum and then increasing for values of outbound greater than $85 \%$.

\begin{tabular}{|c|c|c|c|c|c|c|c|c|}
\hline & \multicolumn{4}{|c|}{ Dependent variable: closed EBIT per employee } & \multicolumn{4}{|c|}{ Dependent variable: closed ROA } \\
\hline Adjusted $\mathrm{R}^{2}$ & \multicolumn{4}{|c|}{, 521} & \multicolumn{4}{|c|}{,42I } \\
\hline $\begin{array}{l}\text { Std. error of the } \\
\text { estimate }\end{array}$ & \multicolumn{4}{|c|}{161,314} & \multicolumn{4}{|c|}{,304 } \\
\hline ANOVA: & \multicolumn{2}{|c|}{ Regression } & \multicolumn{2}{|c|}{ Residual } & \multicolumn{2}{|c|}{ Regression } & \multicolumn{2}{|c|}{ Residual } \\
\hline Sum of squares & \multicolumn{2}{|c|}{17.957 .960} & \multicolumn{2}{|c|}{ 16.237.922 } & \multicolumn{2}{|c|}{42,569} & \multicolumn{2}{|c|}{57,545} \\
\hline df & \multicolumn{2}{|c|}{5} & \multicolumn{2}{|c|}{624} & \multicolumn{2}{|c|}{5,000} & \multicolumn{2}{|c|}{624,000} \\
\hline Mean square & \multicolumn{2}{|c|}{3.591 .592} & \multicolumn{2}{|c|}{26.022} & \multicolumn{2}{|c|}{8,514} & \multicolumn{2}{|c|}{0,092} \\
\hline $\mathrm{F}$ & \multicolumn{4}{|c|}{138,020} & \multicolumn{4}{|c|}{92,321} \\
\hline Sig. & \multicolumn{4}{|c|}{,000 } & \multicolumn{4}{|c|}{,000 } \\
\hline Predictors: & B & Std. error & $\mathrm{t}$ & Sig. & B & Std. error & $\mathrm{t}$ & Sig. \\
\hline constant & 26,224 & 13,258 & 1,978 & ,048 & 5,664 & 2,496 & 2,269 & ,024 \\
\hline inbound & 5,003 & ,942 & 5,312 & , 000 & ,658 & , 177 & 3,711 & ,000 \\
\hline outbound & $-8,689$ & 1,154 & $-7,526$ & , 000 & $-1,718$ & , 217 & $-7,903$ & ,000 \\
\hline inbound $^{2}$ &,- 061 &, 013 & $-4,528$ & , 000 & $-0,009$ & ,003 & $-3,514$ & ,000 \\
\hline outbound ${ }^{2}$ & ,039 & ,016 & 2,408 &, 016 & 0,011 & 0,003 & 3,634 &, 000 \\
\hline inbound*outbound & ,021 & 010 & 1,996 & ,046 & ,005 & ,002 & 2,664 &, 008 \\
\hline
\end{tabular}

Table 8. Quadratic regressions of closed EBIT per employee and closed ROA using inbound and outbound as predictors.

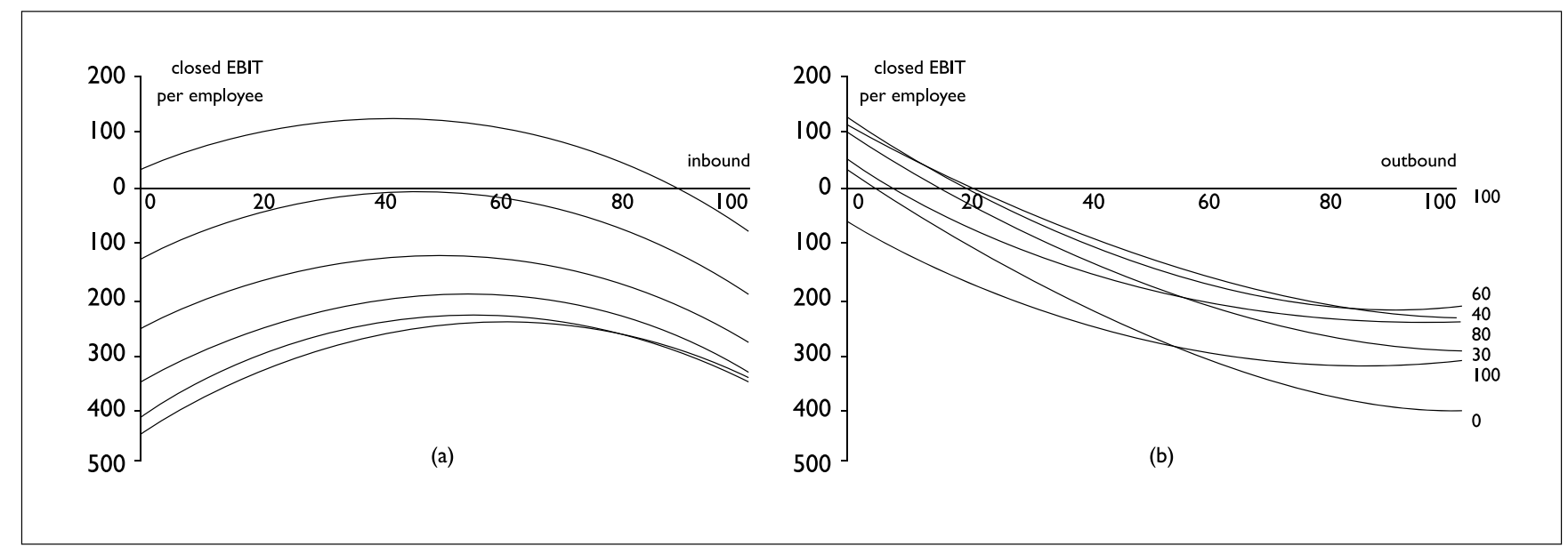

Figure 2. Iso-outbound (a) and iso-inbound (b) curves for closed EBIT per employee.

ISSN: 07I 8-2724. (http://www.jotmi.org) 
The trends of closed ROA are quite similar, with maximum values reached for inbound ranging from $37 \%$ to $67 \%$ and positive values only for outbound less than or equal to $13 \%$. Yet, all the iso-inbound curves here have an $U$ shape, with an increase of performances for outbound greater than or equal to $54 \%$.

A slight recourse to inbound practices provides benefits in terms of costs reduction: companies can access external resources at a lower cost than the one they would incur if only internal resources were used.Yet, when the recourse to external resources increases, the management complexity of such resources is higher than the benefits, thus resulting in an increase of costs.

As to outbound, the negative relation with performances can be considered as industry-specific. Actually, high values of outbound are typical of biotech companies which are mostly focused on the R\&D process and only seldom commercialize products. Thus, a consistent part of their revenues derive from Ol activities such as the selling of R\&D services or the licensing of their IP: 19 companies out of 126 in the sample gain $100 \%$ of their revenues from open innovation in at least one of the five years. These companies are typically in loss and survive only from private investments and government contributions.

A final remark has to be done as to the coefficient of the product of inbound and outbound that, being positive, implies a synergy between open modalities, with performances increasing when both inbound and outbound are performed. In Table 9 a summary of our results is provided.

\section{Conclusions}

The paper analyses the relationship between the adoption of open innovation by companies and their I) context features, 2) R\&D organization and 3) financial performances.

Our results suggest that open innovation is more pervasive among small and young biotech companies, for most of which it is the very core business with most part of revenues deriving from open practices. Yet, higher contributions in terms of total open costs, revenues, additions and disposals are provided by large companies: despite open innovation is not a core activity for them and can be defined as an ancillary activity, due to their larger dimension, higher volumes are exchanged by them in the innovation market.

Even if the number of companies performing inbound and outbound practices is quite similar, the former have a higher entity, the latter a higher intensity. This means that the cumulative value of costs and additions is higher than the cumulative value of revenues and disposals, but, when the four entities are compared to the total volume of business, outbound is more relevant than inbound.

Inbound practices are substitutive to internal R\&D activities, while outbound ones are complementary to internal development: the former provide external knowledge resources as alternative to internal ones, the latter represent the exploitation of innovation results obtained with both internal and external resources.

\begin{tabular}{|l|l|}
\hline Hypothesis & Results \\
\hline Hp. I & $\begin{array}{l}\text { Partially significant, but opposite } \\
\text { sign }\end{array}$ \\
\hline Hp. 2 & Significant, but opposite sign \\
\hline Hp. 3 & No support \\
\hline Hp. 4 & Significant, but opposite sign \\
\hline Hp. 5a & Significant, but opposite sign \\
\hline Hp. 5b & Confirmed \\
\hline Hp. 6 & Partially confirmed \\
\hline
\end{tabular}

Table 9. Summary of the results.

ISSN: 07 I8-2724. (http://www.jotmi.org) 
The performances of companies have an inverted-U shape trend versus inbound practices and a fundamentally decreasing trend versus outbound ones: beyond a certain value of inbound the benefits deriving from leveraging external technologies are exceeded by the costs deriving from the management of external relationships; on the other side, the negative relation between performances and outbound practices can be considered as industryspecific since high values of outbound are typical of biotech companies.

The paper contributes to the debate on open innovation in two ways. First, by suggesting a measurement framework for Ol based on its pecuniary dimension, it provides new insights as to what "being open" means for a company. Actually, most contributions in literature provide a definition of openness linked to the wideness and diversity of open activities and/or alliances portfolio, while our definition is basically linked to how much such activities and alliances influence the business of companies, i.e. how pervasive is openness in the business models of companies. Noteworthy, the two different approaches to openness often lead to different results in terms of relationships with structural configurations and performances. The second contribution, in line with the suggestion by Schroll and Mild (20I I), is the separation of inbound from outbound activities, which leads to a deeper understanding of open innovation.

Three limits can be outlined for the work. First, the disharmony of accounting standards over countries limited our analysis only to the companies which adopted either IFRS or US GAAP, resulting in an under-coverage of the sample. Second, being focused on accounting indicators, our framework can be used to analyse only the pecuniary dimension of open innovation (Dahlander and Gann, 2010) and thus it cannot be generalized to such industries as software, where sourcing and revealing are widespread. Third, the paper is based on observations over a five-years period, which is too short, at least in the analysed industry, to allow a longitudinal analysis.

Further directions of research will be devoted to indepth case studies over longer periods of time, in order to describe the different trajectories to open innovation within the specific industry and understand how open strategies can be related to company's culture. Moreover, the widening of the analysis to the technology hardware and equipment (THE) sector highlighted very different $\mathrm{OI}$ adoption models (Michelino et al. 20l4b); the validation of the suggested hypotheses for the THE industry is now under investigation. 


\section{References}

AHN,J.M., Mortara, L., Minshall,T.(20I3).The Effects of Open Innovation on Firm Performance:A Capacity Approach. STI Policy Review, 4(I), 74-93. Available at SSRN: http://ssrn. com/abstract $=2328625$

BARGE-GIL, A. (20I0). Open, semi-open and closed innovators: towards an explanation of degree of openness. Industry and Innovation, I7(6), 577-607. doi: http://dx.doi.or $g /|0.1080 /| 36627 / 6.2010 .530839$

BIANCHI, M., Cavaliere, A., Chiaroni, D., Frattini, F., Chiesa, V. (20II). Organisational modes for open innovation in the bio-pharmaceutical industry: an exploratory analysis. Technovation, 3I(I), 22-33. doi: http://dx.doi.org/ 10.1016/j. technovation.2010.03.002

CHESBROUGH, H. (2003). Open Innovation: The New Imperative for Creating and Profiting from Technology. Harvard Business School Press, Boston.

CHESBROUGH, H., Crowther, A. K. (2006). Beyond hightech: early adopters of open innovation in other industries. R\&D Management, 36(3), 229-236. doi: http://dx.doi. org/I0.1 II I/j. I467-93I0.2006.00428.x

CHIARONI, D., Chiesa, V., Frattini, F. (2008). Patterns of collaboration along the bio-pharmaceutical innovation process. Journal of Business Chemistry, 5(I), 7-22. Available at http://www.businesschemistry.org/article/?article $=45$

CHIARONI, D., Chiesa, V., Frattini, F. (2009). Investigating the adoption of open innovation in the biopharmaceutical industry: a framework and an empirical analysis. European Journal of Innovation Management, 12(3), 285-305. doi: http://dx.doi.org//0.1 I08//46010609/0974192

COHEN,W. M., Levinthal, D.A. (1990).Absorptive capacity:A new perspective on learning and innovation. Administrative Science Quarterly, 35(I), 128-I52. doi: http://dx.doi. org// 0.2307/2393553

COOKE, P. (2005). Regionally asymmetric knowledge capabilities and open innovation exploring "Globalisation 2" - a new model of industry organization. Research Policy, 34(8), II28-II49. doi: http://dx.doi.org//0.1016/j. respol.2004.12.005

DAHLANDER, L., Gann, D. M. (2007). How open is innovation?. Paper Presented at the DRUID Summer Conference. 18 June 2007. Copenhagen, Denmark.
DAHLANDER, L., Gann, D. M. (2010). How open is innovation?. Research Policy, 39(6), 699-709. doi: http:// dx.doi.org/10.1016/j.respol.2010.01.013

DODGSON, M., Gann, D. M., Salter, A. (2006). The role of technology in the shift towards open innovation: the case of Procter \& Gamble. R\&D Management, 36(3), 333-346. doi: http://dx.doi.org/I0. I I I I/j. I 467-93 I0.2006.00429.x

ENKEL, E., Lenz,A. (2009). Open innovation metrics system. Paper Presented at the R\&D Management Conference. 2I24 June 2009.Vienna, Austria.

FAEMS, D., de Visser, M., Andries, P., van Looy, B. (20I0). Technology alliance portfolios and financial performance: value-enhancing and cost-increasing effects of open innovation. Journal of Product Innovation Management, 27(6), 785-796. doi: http://dx.doi.org//0.1III/j.15405885.20I0.00752.x

FETTERHOFF,T.J.,Voelkel,D.(2006).Managing open innovation in biotechnology. Research-Technology Management, 49(3), 14-|8. Available at http://www.ingentaconnect.com/content/ $\mathrm{iri} / \mathrm{rtm} / 2006 / 00000049 / 00000003 / \mathrm{art} 00003$

GASSMANN, O. (2006). Opening up the innovation process: towards an agenda. R\&D Management, 36(3), 223-228. doi: http://dx.doi.org/I0. I I I I/j. I 467-93 I0.2006.00437.x

GASSMANN, O., Enkel, E. (2004). Towards a theory of open innovation: three core process archetypes. Paper Presented at the R\&D Management Conference. 6-9 July 2004. Lisbon, Portugal.

GASSMANN, O., Reepmeyer, G., von Zedtwitz, M. (2008). Leading Pharmaceutical Innovation: Trends and Drivers for Growth in the Pharmaceutical Industry. Springer, Berlin.

HUIZINGH, E. K. R. E. (20II). Open innovation: state of the art and future perspectives. Technovation, 3I(I), 2-9. doi: http://dx.doi.org/10.1016/j.technovation.2010.10.002

HUNG, K.-P., Chiang,Y.-H.(20 I0). Open innovation proclivity, entrepreneurial orientation, and perceived firm performance. International Journal of Technology Management, 52(3-4), 257-274. doi: http://dx.doi.org/ I0.1504/IJTM.2010.035976

HWANG, J., Lee, Y. (2010). External knowledge search, innovative performance and productivity in the Korean ICT sector. Telecommunications Policy, 34(10), 562-57I. doi: http://dx.doi.org// 0.1016/j.telpol.2010.04.004 
IDRISSIA, M. O.,Amaraa, N., Landrya, R. (20I2). SMEs' Degree of Openness: The Case of Manufacturing Industries. Journal of Technology Management \& Innovation, 7(I), I86-210. doi: http://dx.doi.org/I0.4067/S07I8-272420I2000I 00013

ILI, S., Albers, A., Miller, S. (2010). Open innovation in the automotive industry. R\&D Management, 40(3), 246-255. doi: http://dx.doi.org/I0.I I I I/j. I 467-93 I0.20I0.00595.x

INAUEN, M., Schenker-Wicki, A. (20II). The impact of outside-in open innovation on innovation performance. European Journal of Innovation Management, I4(4), 496-520. doi: http://dx.doi.org/ | 0. I I08//460 I06 I | | | 174934

JU, P.-H., Chen, D.-N.,Yu,Y.-C.,Wei, H.-L. (20I3). Relationships among Open Innovation Processes, Entrepreneurial Orientation, and Organizational Performance of SMEs: The Moderating Role of Technological Turbulence. In: Kobylinski, A., Sobczak, A. (Eds.), Perspectives in Business Informatics Research - 12th International Conference, BIR 2013,Warsaw, Poland, September 23-25. Proceedings, Springer, pp. I40-I60.

KATZ, R., Allen, T. J. (1982). Investigating the Not Invented Here $(\mathrm{NIH})$ syndrome: A look at the performance, tenure, and communication patterns of 50 R\&D Project Groups. R\&D Management, I2(I), 7-20. doi: http://dx.doi.org/ I0.1 III/j. I467-9310.1982.tb00478.x

KEUPP, M. M., Gassmann, O. (2009). Determinants and archetype users of open innovation. R\&D Management, 39(4), 33I-34I. doi: http://dx.doi.org/I0.IIII/j.I467$9310.2009 .00563 . x$

KLEYN, D., Kitney, R., Atun, R. (2007). Partnership and innovation in the life sciences. International Journal of Innovation Management, II(2), 323-347. doi: http://dx.doi. org/I0.1I42/S1363919607001722

KUMAR, N., Saqib, M. (1996). Firm size, opportunities for adaptation and in-house R\&D activity in developing countries: the case of Indian manufacturing. Research Policy, 25(5), 713722. doi: http://dx.doi.org/10.1016/0048-7333(95)00854-3

LAURSEN, K., Salter,A. (2006). Open for innovation: the role of openness in explaining innovation performance among U.K. manufacturing firms. Strategic Management Journal, 27(2), | 3|-| 50. doi: http://dx.doi.org/ |0.1002/smj.507

LAZZAROTTI, V., Manzini, R., Pellegrini, L. (2010). Open innovation models adopted in practice: an extensive study in Italy. Measuring Business Excellence, I4(4), I I-23. doi: http:// dx.doi.org/|0.1 I08//368304/01 I09372|
LEE, S., Park, G., Yoon, B., Park, J. (20I0). Open innovation in SMEs - An intermediated network model. Research Policy, 39(2), 290-300. doi: http://dx.doi.org//0.1016/j. respol.2009.12.009

MICHELINO, F., Lamberti, E., Cammarano, A., Caputo, M. (20I4a).Measuring open innovation in the bio-pharmaceutical industry. Creativity and Innovation Management (Article in Press). doi: http://dx.doi.org/ 10.1 I I I/caim. 12072

MICHELINO, F., Cammarano, A., Lamberti, E., Caputo, M. (20I4b). Open models for innovation of leading companies in high competitive industries. Proceedings of the 23rd International Business Information Management Association Conference - IBIMA. 13-I4 May 20I4.Valencia, Spain.

PODMETINA, D., Väätänen, J., Torkkeli, M. T., Smirnova, M. M. (20II). Open innovation in Russian firms: an empirical investigation of technology commercialisation and acquisition. International Journal of Business Innovation and Research, 5(3), 298-3 I7. doi: http://dx.doi.org//0.1504/ IJBIR.20II.040I00

POWELL, W., White, D., Koput, K., Owen-Smith, J. (2005). Network dynamics and field evolution: the growth of interorganizational collaboration in the life sciences. American Journal of Sociology, I I (4), I I 32- I 205. doi: http:// dx.doi.org//0.1086/42I508

SANDULLI, F. D., Fernandez-Menendez,J., Rodriguez-Duarte, A., Lopez-Sanchez, J. I. (20I2). Testing the Schumpeterian hypotheses on an open innovation framework. Management Decision, 50(7), 1222-I232. doi: http://dx.doi.org//0.2139/ ssrn. 1978403

SCHROLL, A., Mild, A. (20II). Open innovation modes and the role of internal R\&D: An empirical study on open innovation adoption in Europe. European Journal of Innovation Management, I4(4), 475-495. doi: http://dx.doi. org/ I0.1108/I460106IIIIII74925

TEIRLINCK, P., Poelmans, E. (20I2). Open innovation and firm performance in small-sized R\&D active companies in the chemical industry: the case of Belgium. Journal of Business Chemistry, 9(3), I 17-132. Available at http://www. businesschemistry.org/article/?article $=160$

VAN DE VRANDE, V., de Jong, J. P. J., Vanhaverbeke, W., de Rochemont, M. (2009). Open innovation in SMEs: Trends, motives and management challenges. Technovation, 29(6-7), 423-437. doi: http://dx.doi.org/ 10.1016/j. technovation.2008.10.00 I 
VAN DER MEER, H. (2007). Open innovation-the Dutch treat: challenges in thinking in business models. Creativity and Innovation Management, 16(2), 192-202. doi: http:// dx.doi.org/I0.I I I I/j.I467-869I.2007.00433.x

WEST, J., Gallagher, S. (2006). Challenges of open innovation: the paradox of firm investment in open-source software. R\&D Management, 36(3), 319-33I. doi: http://dx.doi. org/I 0.1 III/j. I467-93/0.2006.00436.x

WIKLUND, J., Shepherd, D. (2003). Knowledge-based resources, entrepreneurial orientation, and the performance of small and medium-sized businesses. Strategic Management Journal, 24(|3), |307-|3|4. doi: http://dx.doi.org//0.1002/ smj.360 
Appendix

\begin{tabular}{|c|c|c|c|c|c|c|c|c|}
\hline COMPANY & INDUSTRY & COUNTRY & COMPANY & INDUSTRY & COUNTRY & COMPANY & INDUSTRY & COUNTRY \\
\hline 4SC & biotech & $\mathrm{D}$ & Illumina & biotech & USA & Teva & pharma & IL \\
\hline Abbott & pharma & USA & Impax & biotech & USA & Theravance & pharma & USA \\
\hline Ablynx & biotech & B & Incyte & biotech & USA & $\begin{array}{l}\text { Thrombo- } \\
\text { Genics }\end{array}$ & biotech & B \\
\hline Actelion & pharma & $\mathrm{CH}$ & Innate & biotech & $\mathrm{F}$ & TiGenix & biotech & B \\
\hline Active & biotech & $S$ & Intercell & biotech & $A$ & TopoTarget & biotech & DK \\
\hline Affymetrix & biotech & USA & Ipsen & pharma & $\mathrm{F}$ & Transgene & biotech & $\mathrm{F}$ \\
\hline Alexion & biotech & USA & Isis & biotech & USA & UCB & pharma & B \\
\hline ALK-Abello & pharma & DK & J\&J & pharma & USA & United & biotech & USA \\
\hline Alkermes & pharma & USA & Krka & pharma & SLO & Vectura & pharma & UK \\
\hline Allergan & pharma & USA & Lab Rovi & pharma & $E$ & Vernalis & biotech & UK \\
\hline Almirall & pharma & $E$ & Lexicon & biotech & USA & Vertex & biotech & USA \\
\hline Amgen & biotech & USA & Life Tech & biotech & USA & Vetoquinol & pharma & $\mathrm{F}$ \\
\hline Arena & pharma & USA & Lundbeck & pharma & DK & Warner & pharma & IRL \\
\hline Ark & biotech & UK & Meda & pharma & $S$ & Wilex & biotech & $\mathrm{D}$ \\
\hline AstraZeneca & pharma & UK & Medicines & pharma & USA & Zealand & biotech & DK \\
\hline Basilea & biotech & $\mathrm{CH}$ & MediGene & biotech & $\mathrm{D}$ & Zeltia & pharma & $E$ \\
\hline Bavarian & biotech & DK & Medivir & pharma & $S$ & & & \\
\hline Biogen & biotech & USA & Merck DE & pharma & $\mathrm{D}$ & & & \\
\hline Bioinvent & biotech & $S$ & Merck US & pharma & USA & & & \\
\hline Biomarin & biotech & USA & Merz & pharma & $\mathrm{D}$ & & & \\
\hline Biotest & pharma & $\mathrm{D}$ & Morphosys & biotech & $\mathrm{D}$ & & & \\
\hline Biotie & biotech & FIN & Mylan & pharma & USA & & & \\
\hline Bioton & pharma & PL & Nektar & biotech & USA & & & \\
\hline Boehringer & pharma & $\mathrm{D}$ & NeuroSearch & biotech & DK & & & \\
\hline Bristol-MS & pharma & USA & Newron & biotech & I & & & \\
\hline BTG & biotech & UK & $\mathrm{NicOx}$ & pharma & $\mathrm{F}$ & & & \\
\hline Celgene & biotech & USA & Novartis & pharma & $\mathrm{CH}$ & & & \\
\hline $\mathrm{CHR}$ & pharma & DK & NovoNordisk & pharma & DK & & & \\
\hline Cosmo & pharma & I & Novozymes & biotech & DK & & & \\
\hline CSL & biotech & AUS & NPS & biotech & USA & & & \\
\hline Cubist & biotech & USA & Oasmia & pharma & $S$ & & & \\
\hline Dechra & pharma & UK & Omega & pharma & B & & & \\
\hline Dendreon & biotech & USA & Onyx & pharma & USA & & & \\
\hline Diamyd & pharma & $S$ & Orexo & pharma & $S$ & & & \\
\hline DiaSorin & pharma & 1 & Orion Oyj & pharma & FIN & & & \\
\hline Egis & pharma & $\mathrm{H}$ & Oxford & pharma & UK & & & \\
\hline Elan & pharma & IRL & Paion & biotech & $\mathrm{D}$ & & & \\
\hline Eli Lilly & pharma & USA & Perrigo & pharma & USA & & & \\
\hline Endo & pharma & USA & Pfizer & pharma & USA & & & \\
\hline Epigenomics & biotech & $D$ & Pharming & biotech & NL & & & \\
\hline Evotec & pharma & $\mathrm{D}$ & Qiagen & biotech & $\mathrm{NL}$ & & & \\
\hline
\end{tabular}

ISSN: 07I8-2724. (http://www.jotmi.org)

Journal of Technology Management \& Innovation (c) Universidad Alberto Hurtado, Facultad de Economía y Negocios. 


\begin{tabular}{|l|l|l|l|l|l|l|l|l|}
\hline Exelixis & pharma & USA & Recordati & pharma & I & & \\
\hline Forest & pharma & USA & Regeneron & biotech & USA & & \\
\hline Galapagos & biotech & B & Roche & pharma & CH & & \\
\hline Galenica & pharma & CH & Salix & pharma & USA & & \\
\hline Gedeon & pharma & H & Sanofi-Aventis & pharma & F & & \\
\hline Genmab & biotech & DK & Seattle & biotech & USA & & \\
\hline Genus & biotech & UK & Shire & pharma & UK & & \\
\hline Geron & biotech & USA & Silence & biotech & UK & & \\
\hline Gilead & biotech & USA & SkyePharma & pharma & UK & & \\
\hline GSK & pharma & UK & SOB & biotech & S & & \\
\hline Guerbet & pharma & F & Stada & pharma & D & & \\
\hline GW & pharma & UK & Sygnis & biotech & D & & \\
\hline Hikma & pharma & UK & Symphogen & biotech & DK & & \\
\hline Hospira & pharma & USA & Targacept & biotech & USA & & \\
\hline
\end{tabular}

